\title{
Geophysical Imaging of a Buried Tertiary Valley Aquifer in an Arid Region Using Time Domain Electromagnetic Method
}

\author{
Mahmoud M. Elwaheidi \\ Department of Geology and Geophysics, College of Science, King Saud University, Riyadh, Saudi Arabia \\ Email: melwaheidi@ksu.edu.sa
}

How to cite this paper: Elwaheidi, M. M. (2020). Geophysical Imaging of a Buried Tertiary Valley Aquifer in an Arid Region Using Time Domain Electromagnetic Method. Journal of Geoscience and Environment Protection, 8, 195-206.

https://doi.org/10.4236/gep.2020.87011

Received: July 2, 2020

Accepted: July 27, 2020

Published: July 30, 2020

Copyright $\odot 2020$ by author(s) and Scientific Research Publishing Inc. This work is licensed under the Creative Commons Attribution International License (CC BY 4.0).

http://creativecommons.org/licenses/by/4.0/

\section{(c) (i) Open Access}

\begin{abstract}
A time domain electromagnetic survey was conducted in the eastern part of the Jordanian desert to image a buried Tertiary valley aquifer in the context of the characterization of groundwater resources and groundwater resources management. The Tertiary chert-limestone rocks (B4) of the investigated valley constitute the major part of the shallow-depth aquifer (less than $100 \mathrm{~m}$ ) which is the main source of water in the area. Thus, delineation of the geometry of the valley deems necessary for a better understanding of its structural setting and hydrogeological potential. For this purpose, 141 central-loop sounding stations were conducted in the area; they were positioned along six NE-SW directed profiles and one profile (TDEM profile 1) that extends for about $9 \mathrm{~km}$ in the NW-SE direction. Resistivity pseudo-sections and resistivity depth maps reveal that the subsurface is composed of two main geoelectric layers: a resistive layer of $25-40 \mathrm{ohm} . \mathrm{m}$ that indicates the water-bearing rocks which is composed of an alteration of massive chert and limestone. The second layer is conductive one that has a resistivity values in the range from 10 to $15 \mathrm{ohm} . \mathrm{m}$; it consists mainly of gravel and bituminous marl. A lateral variation in resistivity that is associated with the presence of block-like structures is also noted. The good contrast in resistivity between the B4 chert-limestone water-bearing rocks and marl layer enhanced the obtained results and proved that the TDEM is efficient in imaging the boundaries of the Tertiary valley. The lateral extensions of the valley were well-imaged at three fixed-elevation slices (550, 500 and $450 \mathrm{~m}$ amsl). The subsurface elongation direction of the valley is confirmed by the NW-SE surface elongation of the valley. The vertical boundary of the valley is extended to an elevation of at least $450 \mathrm{~m}$ amsl; this corresponds to a depth of about $100 \mathrm{~m}$.
\end{abstract}

\section{Keywords}

TDEM, Geophysical Imaging, Buried Valley, Aquifer, Jordan 


\section{Introduction}

Electromagnetic methods such as Time-domain Electromagnetic Method (TDEM) can map subsurface layers and distinguish their lithology due to the contrast in the electrical properties (conductivity) of earth materials. These properties are function of several factors that include rock porosity, grain size and type of fluids filling the pores (Keller, 1988).

The non-invasive nature and the rapid field procedure make the TDEM a valid geophysical method in investigating and imaging subsurface stratification and structures such as faults and buried valleys. This is particularly significant in characterizing subsurface structural features which has critical role in controlling the characteristics of groundwater resources. Specifically, buried-valley aquifers are widely known as vital sources of water in arid areas that suffer from scarcity of water resources and heavily depend on groundwater resources for drinking, domestic, agricultural and industrial uses. Numerous case studies have been reported in the literature that demonstrated the successful use of geophysical methods for structural and hydrogeological investigations, and for mapping of buried valleys (Danielsen et al., 2003; Jørgensen et al., 2003; Sandersen \& Jørgensen, 2003; Christiansen et al., 2006; Bedrosian et al., 2013; Sharma \& Baranwal, 2005; Gonçalves et al., 2017).

The current research aims to provide a resistivity-based model of the subsurface stratification and to characterize a Tertiary buried valley aquifer in an arid area that is located at the northeastern part of the Jordanian desert. The research outcomes will significantly contribute to the efforts made for surface water harvesting in the area. Furthermore, the research will provide an interesting case study on the application of the TDEM method for structural investigations in arid areas; a case that is not common in the literature. During the geophysical survey, 141 TDEM sounding stations were carried out using the square central loop configuration with a $100 \times 100 \mathrm{~m}$ side length. The stations were distributed a long 7 profiles; 6 profiles were oriented NE-SW and one long profile (about $9 \mathrm{~km}$ ) was oriented in the NW-SE direction running along the main wadi in the area.

\section{The Study Area}

The study area is a sub-catchment of the major Azraq Basin that is located about $100 \mathrm{~km}$ northeast of Amman, the capital city of Jordan (Figure 1). The basin has significant importance in terms of available natural reserves, hydrogeological and economical resources. Consequently, the basin has been extensively subjected to numerous geological and geophysical studies that dealt with the basin's geological evolution and the threats to its groundwater resources and natural biodiversity (Abed, 2018; El-Waheidi et al., 1992; Al-Homoud et al., 1995; Al-Hadidi \& Subah, 2001; Alsharifa \& Marwan, 2010; Baird et al., 1992; Henton et al., 2018).

The area is characterized by an arid climate with an average annual rainfall of about $125 \mathrm{~mm}$. It is dominated by a main wadi that runs from west to east with a 


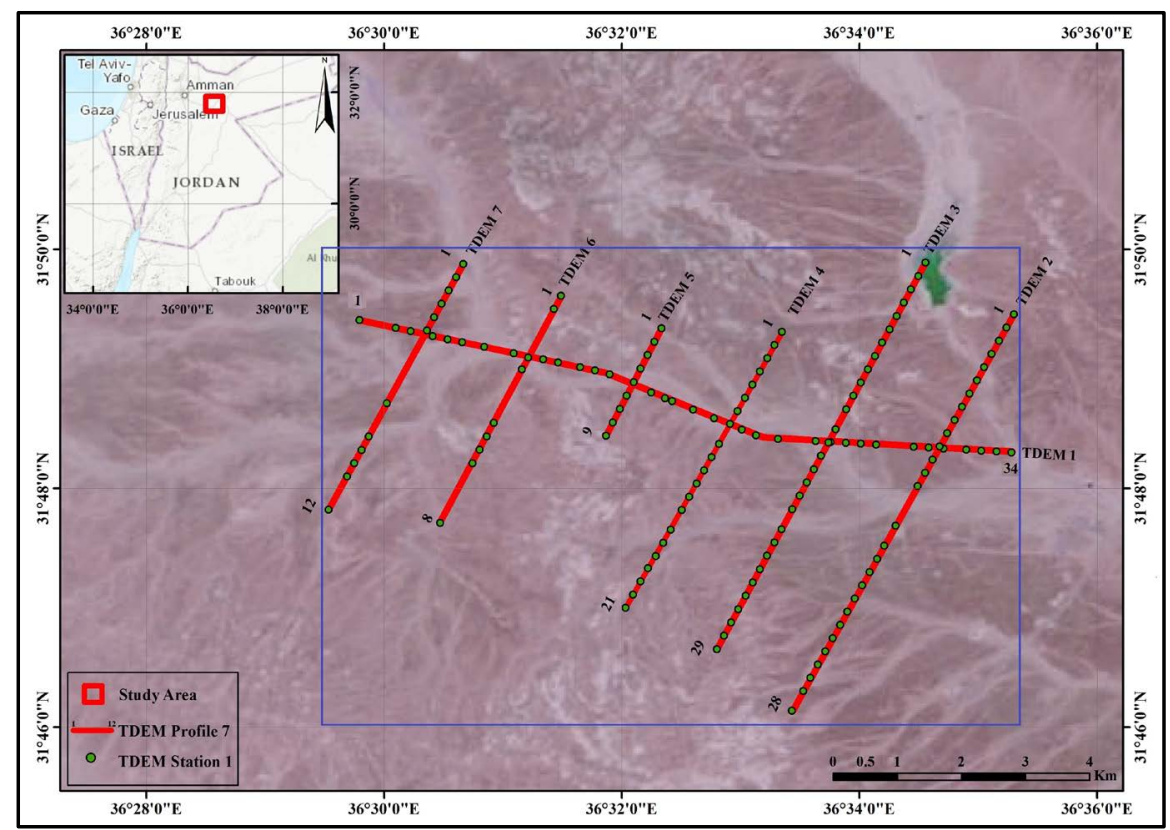

Figure 1. Location map of the study area. Locations of all TDEM sounding stations and TDEM profiles are also shown (Modified after: Google Earth, 2019).

length of about $20 \mathrm{~km}$. Topographically, the highest point in the area is about $750 \mathrm{~m}$ above mean seal level (a.m.s.l) while the lowest one is about $500 \mathrm{~m}$ a.m.s.l (Wheater, 1996).

Geologically (Figure 2), Azraq Basin makes part of the limestone plateau in eastern Jordan that is dominated in its northeastern part by basaltic lava originated from Miocene-Oligocene volcanic activity (Bender, 1975; Ibrahim, 1996).

The sedimentary cover in the investigated part of Azraq basin is composed of several geological formations. The most recent are the alluvial and wadi deposits that are mainly composed of sand and silts. Wadi Shallaleh (B5) formation is composed of chalk intercalated with thin layers of marl, chert and limestone. The B5 formation is underlain by the Umm Rijam formation (B4); it is composed of silicified limestone with thin beds of chert and considered the main aquifer in the area. The formation has a thickness of $100 \mathrm{~m}$ that increases with the regional tilt direction towards the east to reach up to $300 \mathrm{~m}$. Muwaqqar formation (B3) underlies the B4 formation; it is composed of chalky marl, marl and chalky limestone. The thickness of B3 formation is in the range of $120-290 \mathrm{~m}$ (Drury, 1993). The detailed lithostratigraphy of rock units in Azraq Basin (Figure 3) is obtained from numerous wells drilled in the basin for groundwater and oil exploration purposes.

Structurally, Azraq basin is tectonically active and mainly dominated by several regional structures that include fault and lineament systems (Figure 4). These systems have various direction; however, it is believed that the NW-SE and E-W systems played the significant role in the development of the geological setting of the basin. Folds are limited in the area and have small dip where the regional dip is towards northeast (Shahbaz \& Sunna, 2000). 


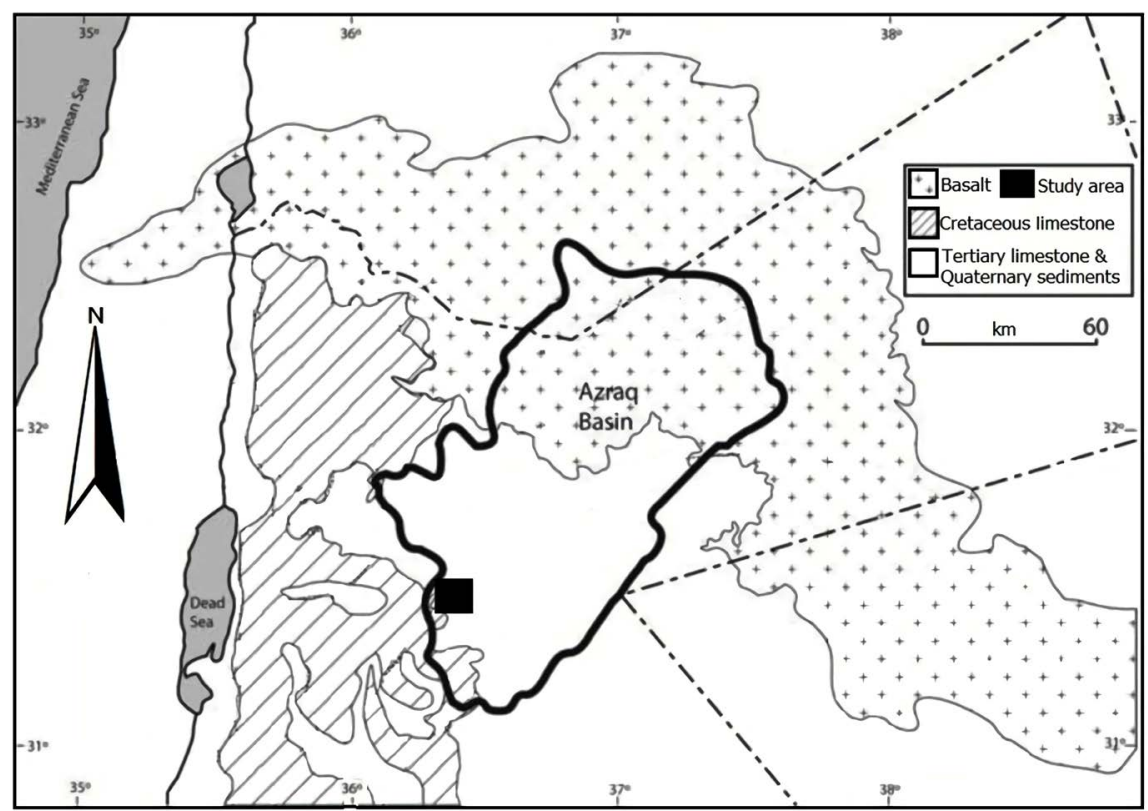

Figure 2. Geological map of Azraq Basin. (Modified after: Henton et al., 2018).

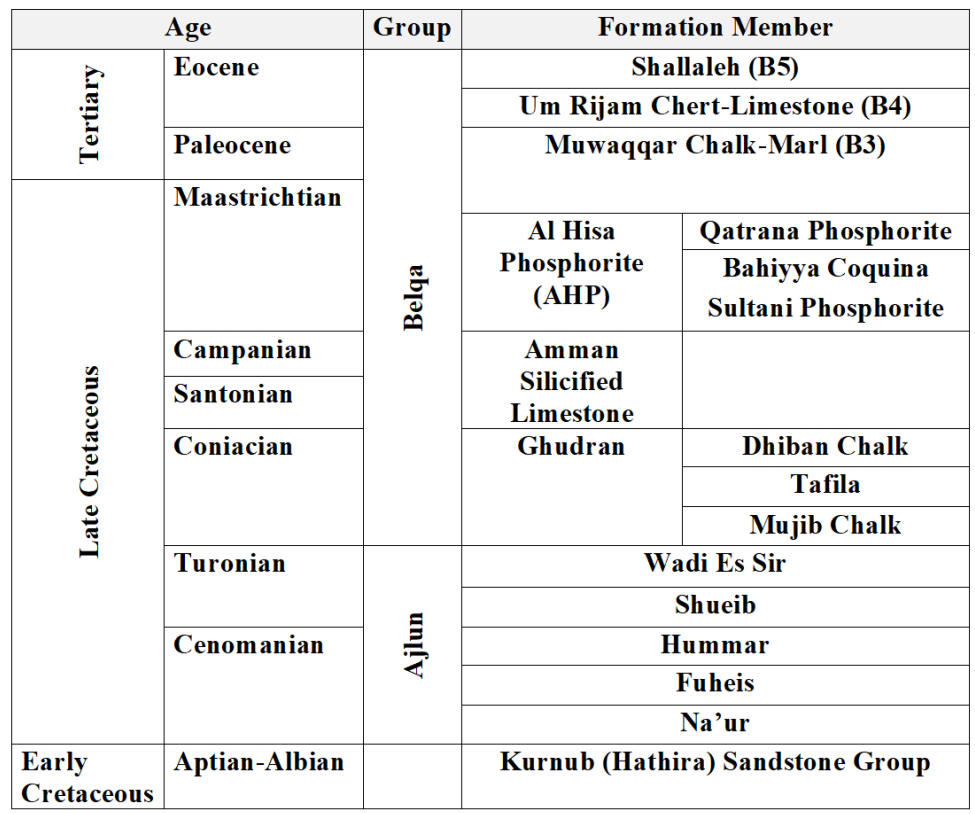

Figure 3. Lithostratigraphy of rock units in Azraq Basin (After: Abed, 2018; Powell, 1989).

\section{Materials and Method}

Geoelectric sounding using TDEM has been applied to investigate the electrical properties of the subsurface and to map the lateral and vertical extensions of a buried valley. The use of TDEM sounding has a significant advantage over conventional DC- resistivity sounding in terms of speed of operation (up to 30 soundings per day could be completed in a limited area) and the depth of penetration compared to the required dimension of the measuring array. 


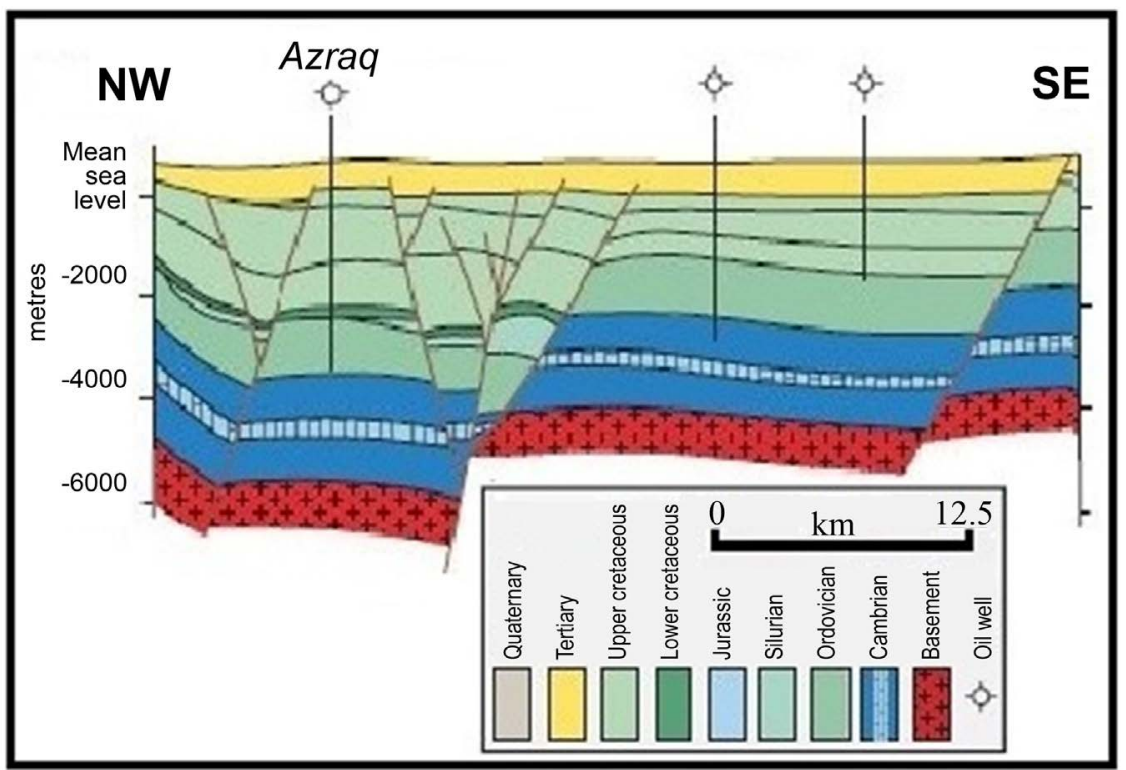

Figure 4. Geological cross section in Azraq Basin (Modified after: Naylor et al., 2013).

Furthermore, and unlike the case in the frequency-domain electromagnetic methods, the induced magnetic response in TDEM is measured in the absence of the stronger primary field. This would facilitate processing of the data since there will be no need to remove the effect of the primary field, a process that is susceptible to lack of accuracy and reduce the signal to noise ratio (Fainberg, 1999; Campaña et al., 2015; McNeill, 1994, 1990; Keller \& Frischknecht, 1966).

\subsection{Basic Principle of TDEM}

The principle of TDEM method, as in all electromagnetic methods, is based on the fact that a primary magnetic field varies in time and thus, according to the Maxwell equations, induces an electrical current in the surroundings. The induced magnetic and electrical fields are called secondary fields (Figure 5).

The field procedure is carried out by injecting few Amperes square waveform current in a transmitter loop. This produces a primary magnetic field. The current is switched off abruptly. According to Faraday's law, the resulting change in the primary magnetic field induces an electromotive force in the conducting surroundings. The induced current will, in turn, produce a decaying secondary magnetic field that is vertical in the middle of the transmitter loop. Hereby, an electromotive force is induced in the receiver coil; this signal is measured as a function of time (Kaufman \& Keller, 1983; Nabighian \& Macnae, 1991).

The measured voltage response is composed of three stages; the early stage where the response is constant with time, an intermediate stage where the response continually varies with time, and the late stage in which the response takes the form of a straight line (Barrocu \& Ranieri, 2000). The variation of response with time is given by Equation (1):

$$
V(t)=\frac{K 1 M \sigma^{3 / 2}}{t^{5 / 2}}
$$




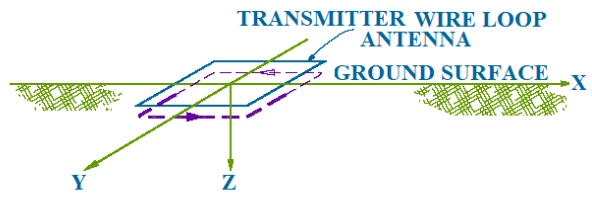

a) Eddy currents immediately after current turnoff.

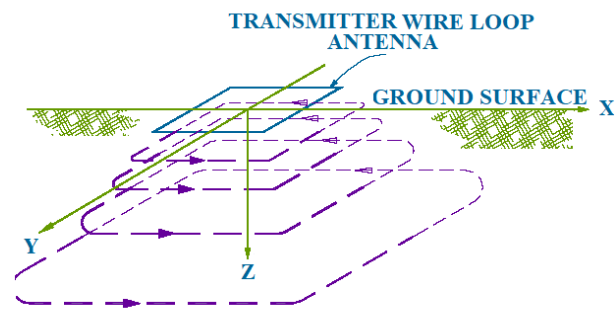

b) Eddy currents at later times.
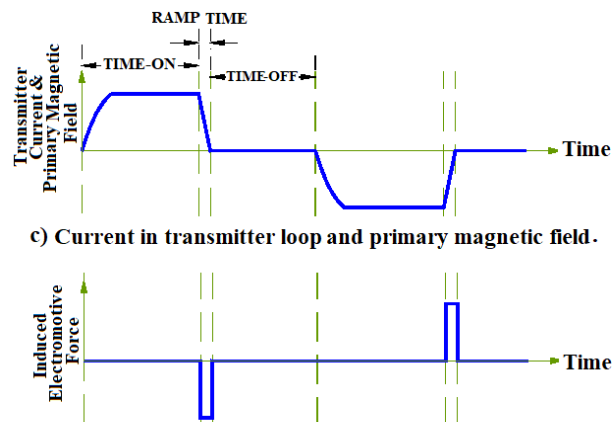

d) Electromotive force induced in the earth and nearby targets by the rapid transmitter current turn-off.

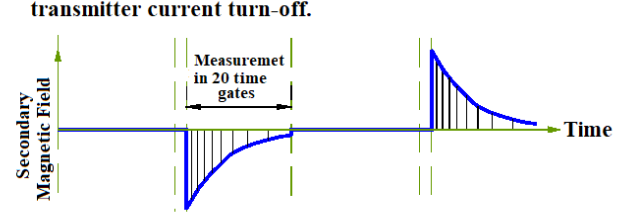

e) Secondary magnetic field resulting from eddy current flow in the earth and nearby targets.

Figure 5. Illustration of the basic principles of TDEM method. (a) eddy currents are formed after the transmitted current is turned off; (b) eddy currents at later times; (c) current in transmitter loop and primary magnetic field; (d) electromotive force induced in the earth after the abrupt turn-off of the primary current; (e) secondary magnetic field resulting from eddy current flow in the earth (McNeill, 1994).

where $K 1=$ a constant

$M=$ product of the transmitter current $(\mathrm{amps}) \times$ area $\left(\mathrm{m}^{2}\right)$

$\sigma=$ terrain conductivity (Siemens $/ \mathrm{m})$

$t=$ time (seconds), and $V(t)=$ output voltage from a single turn receiver coil of one $\mathrm{m}^{2}$ area.

Taking in consideration that resistivity is the reciprocal of conductivity, Equation (1) can be written in terms of apparent resistivity $(\rho a)$ as:

$$
\rho a(t)=\frac{K 2 M^{2 / 3}}{e(t)^{2 / 3} t^{5 / 3}}
$$

As time $(t)$ increases, the depth reached by the current loops is also increased; thus, resistivity sounding with depth can be carried out.

\subsection{Data Acquisition and Processing}

Field data acquisition was carried out using Geonics EM-47 and EM-37 systems. All soundings were carried out using central loop arrays with a loop size of 100 by $100 \mathrm{~m}$. In each system, the vertical component of the transient signal was recorded at two base frequencies: at UHF $(262 \mathrm{~Hz})$ and VHF $(62.5 \mathrm{~Hz})$ for EM-47 system, and at HF $(25 \mathrm{~Hz})$ and MF $(6.25 \mathrm{~Hz})$ for EM-37 system.

In order to statistically improve the signal-to-noise ratio (SNR), the responses were recorded and averaged 256 times at each base frequency. In addition, at least 3 repeat measurements of the vertical field were carried out at each frequency. Such a procedure facilitated optimum setting of the receiver gain, provided more flexible control of the measurement quality and, thus, improve the SNR. Furthermore, positions of sounding stations were selected away from high-power lines and other sources of noise. 
In most cases, the TDEM sounding stations were positioned at approximately $200 \mathrm{~m}$ intervals along profiling lines. Where topographic or other obstacles prevented location of the sounding at this interval, the measurement site was moved along the profiling line to the nearest possible location. The horizontal position and elevation of each sounding site were recorded in UTM and meters above mean sea level, respectively, using a differential GPS instrument.

All instrument checks such as null check, gain check and calibration of the receiver were performed. In addition, the systems have been tested at a fixed test site prior to the survey and after completing the survey. The quality of the acquired data was good in the time range between 0.016 to approximately $10 \mathrm{msec}$. The signal was found distorted out of this range, thus was removed during the processing. Acquired data were stored on a built-in data logger and later were dumped to a personal computer using Geonics PROTEM GSPX7 software.

The acquired TDEM data were processed and interpreted using a standard 1-D interpretation package, TEMIXGL, by Interpex LTD, USA (Interpex, 1994). The interpreted 1-D models were then used to produce pseudo-2D resistivity cross-sections and depth map slices at selected elevations. Data processing included display of the recorded signals, comparison of repeated measurements and selection of the least distorted, removal of distorted points from the records, selection of optimum combination of base frequencies and editing of measuring parameters.

\section{Results and Discussion}

A total of 141 TDEM sounding stations using a $100 \times 100 \mathrm{~m}$ side central loop configuration were carried out in the study area. The stations are distributed along 7 profiles; profile 1 is the longest (about $9 \mathrm{~km}$ long) and directed NW-SE. Profiles 2 to 7 are positioned perpendicularly to profile 1 in the NE-SW direction and distributed at a separating distance in the range of about $1-1.5 \mathrm{~km}$. Such distribution of sounding stations allowed the representation of the TDEM 1-D models in pseudo-2D geoelectric sections and interpreted resistivity maps at selected three elevation slices.

The 2-D resistivity pseudo-sections were compiled by interpolating the appropriate 1-D resistivity versus depth models. In these sections, warm and hot colors correspond to the low resistivity layer of bituminous marls marl (aquiclude) and, possibly, gravels (especially, if the warm colors are located in upper parts of the cross-sections) in the range 10 to $15 \mathrm{ohm} . \mathrm{m}$. Cool colors represent the high resistivity unit ( 25 to more than $40 \mathrm{ohm} . \mathrm{m}$ ) of the Tertiary aquifer that is composed of limestone intercalated with chert. Figure 6 shows the 2D resistivity pseudo-section of TDEM profile 2 that runs in the N-S direction. This is the only profile that is controlled by a lithological log provided by a well drilled about 600 m from sounding station 16 .

Resistivity values obtained for the B4 and B3 rock units fits well within the range of resistivity values expected for similar lithological rocks and with values obtained in previous studies conducted in nearby areas using DC-resistivity methods (Palacky, 1988; El-Waheidi et al., 1992; El-Kaysi \& Talat, 1996). Further 
control of the quality of interpretation is implemented by comparing the resistivity models obtained at 6 points of intersection (Figure 7).

Furthermore, it is interesting to note that all roughly N-S cross-sections (Profiles 2 - 7) have a very clear high resistivity feature where they intersect profile 1 oriented along the main wadi. This feature, however, is not continuous as it would be expected considering only the meridional cross-sections, but rather complicated including intercalation of both resistive and conductive structures.

The geometry of the main structure dominating the area can be better imaged considering the interpreted resistivity maps at selected elevations (3-D representation). For this purpose, three elevation resistivity slices were constructed to image the buried valley; namely at 550, 500 and $450 \mathrm{~m}$ amsl (Figure 8). The

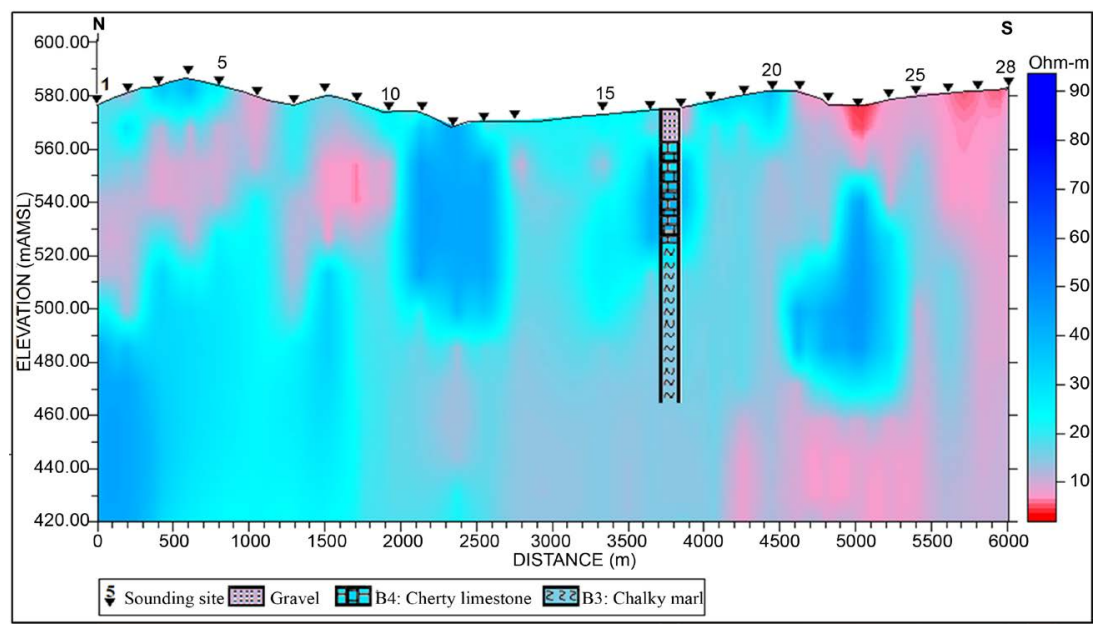

Figure 6. 2D resistivity pseudo-section of TDEM profile 2 that runs in the N-S direction. Typical lithological succession obtained from a well that is located close to sounding stations 16 and 17 is also shown for the sake of correlation between resistivity and lithological units in the area.

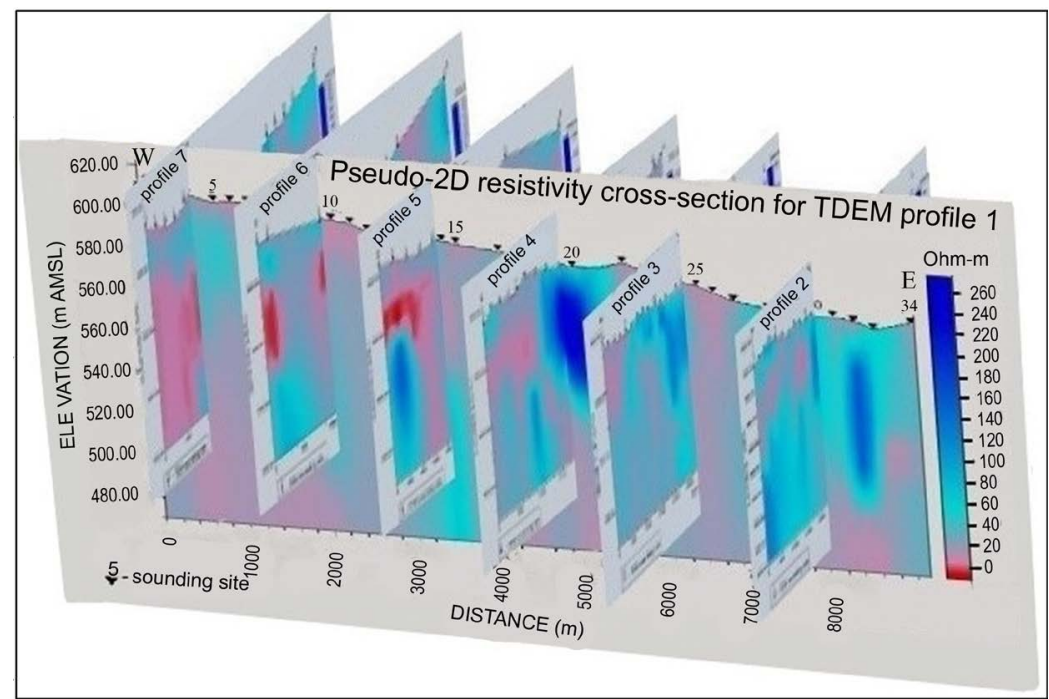

Figure 7. Resistivity pseudo-sections of TDEM profiles 2 to 7 intersected with the pseudo-section of TDEM profile 1. 


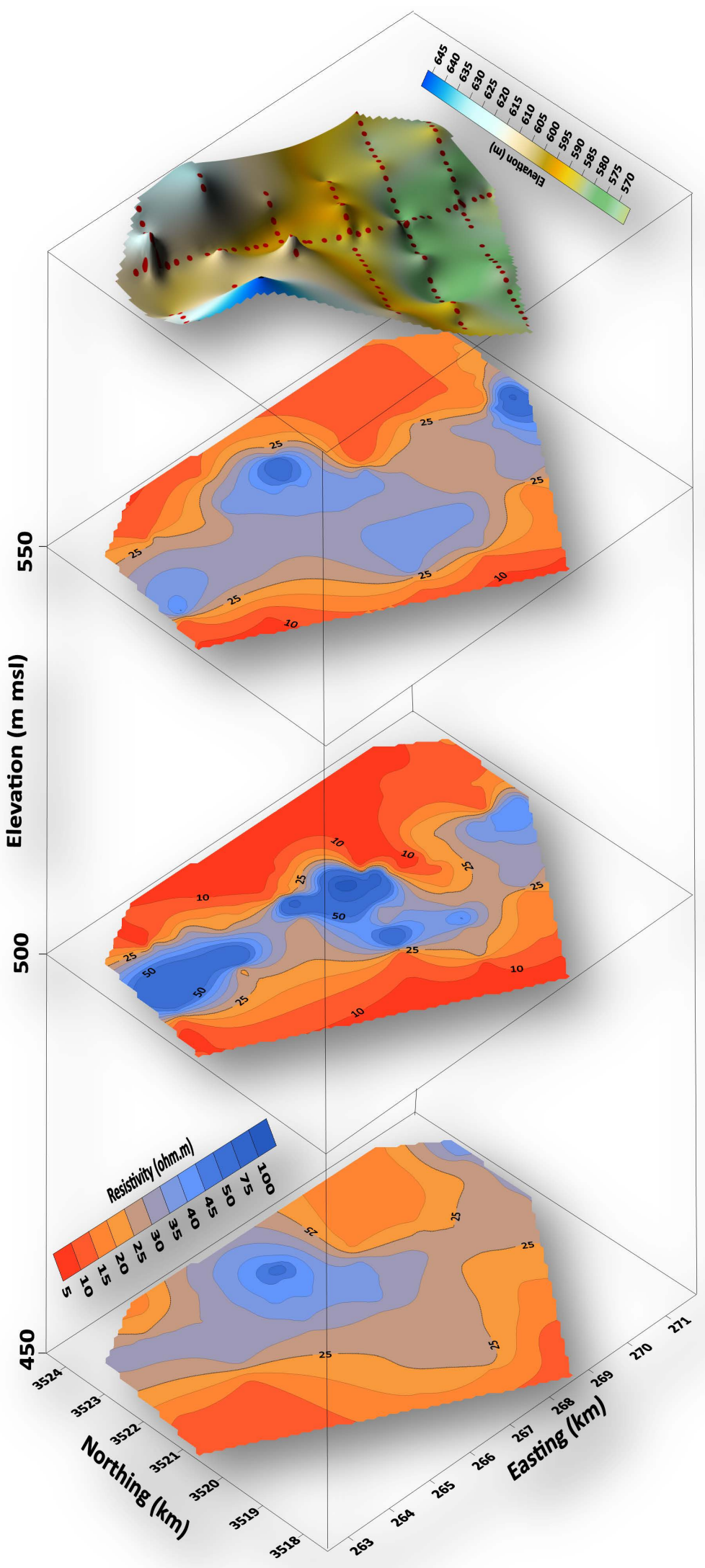

Figure 8. Resistivity distribution at three different elevation 550, 500 and $450 \mathrm{~m}$ amsl. The buried valley boundaries are clearly delineated by resistivity contour line 25 ohm.m. 
three elevation slices clearly show a resistivity structure running along profile 1. This structure most probably represents the buried Tertiary valley. The lateral extensions of the valley are delineated by the resistivity contour line of $25 \mathrm{ohm} . \mathrm{m}$. Although the structure is extended across the three elevation levels, with depth increasing (decreasing the elevation), the dimensions of the resistive structure is becoming smaller.

\section{Conclusion}

TDEM sounding survey using a $100 \times 100 \mathrm{~m}$ central loop configuration was employed to investigate a buried Tertiary valley aquifer that is considered a major source of water in an arid area, northeast of Jordan. The method is proved efficient and succeeded in mapping the lateral and vertical extensions of the valley. TDEM data representation in 2-D and 3-D allowed a reasonable imaging of the buried Tertiary Valley both laterally and in depth. The chert-limestone aquifer (B4 unit), which makes the main rock unit of the valley, has a resistivity in the range $25-50$ ohm.m and an average thickness of about $50 \mathrm{~m}$. To further enhance the derived resistivity model, a high-resolution seismic reflection survey should be conducted along the TDEM profiles. In specific, this would assess in verifying and enhancing the structural interpretation. Furthermore, drilling test wells at selected sites will provide direct geological data (borehole logs) that will greatly help refine the derived model.

\section{Conflicts of Interest}

The author declares no conflicts of interest regarding the publication of this paper.

\section{References}

Abed, A. M. (2018). Geological Evolution of the Azraq Basin, Eastern Jordan: An Overview. Jordan Journal of Natural History, 5, 6-52.

Al-Hadidi, K., \& Subah, A. (2001). Jordan Badia Research and Development Program: Integrated Studies of Azraq Basin for Optimum Utilization of the Natural Resources, Water Group (p. 4). Unpublished Report, Amman: The Higher Council for Science and Technology.

Al-Homoud, A. S., Allison, R. J., Sunna, B. F., \& White, K. (1995). Geology, Geomorphology, Hydrology, Groundwater and Physical Resources of the Desertified Badia Environment in Jordan. GeoJournal, 37, 51-67. https://doi.org/10.1007/BF00814885

Alsharifa Hind, J., \& Marwan, A. (2010). Assessing Groundwater Vulnerability in Azraq Basin Area by a Modified DRASTIC Index. Journal of Water Resource and Protection, 2, 944-951.

Baird, D., Garrard, A., Martin, L., \& Wright, K. (1992). Prehistoric Environment and Settlement in the Azraq Basin: An Interim Report on the 1989 Excavation Season. Levant, 24, 1-31. https://doi.org/10.1179/007589192790212792

Barrocu, G., \& Ranieri, G. (2000). TDEM: A Useful Tool for Identifying and Monitoring the Fresh-Saltwater Interface. In 16th Salt Water Intrusion Meeting (Vol. 12, No. 15, pp. 1-7). Wolin Island (Poland): SWIM. http://www.swim-site.nl/pdf/swim16.html 
Bedrosian, P. A., Burgess, M. K., \& Nishikawa, T. (2013). Faulting and Groundwater in a Desert Environment: Constraining Hydrogeology Using Time-Domain Electromagnetic Data. Near Surface Geophysics, 11, 545-555. https://doi.org/10.3997/1873-0604.2013043

Bender, F. (1975). Geology of the Arabian Peninsula (p. 560). Jordan, MN: US Geological Survey Professional Paper. https://doi.org/10.3133/pp560I

Christiansen, A. V., Auken, E., \& Sørensen, K. I. (2006). The Transient Electromagnetic Method. In R. Kirsch (Ed.), Groundwater Geophysics, a Tool for Hydrogeology (pp. 179-224). Berlin: Springer. https://doi.org/10.1007/3-540-29387-6_6

Campaña, J. D. R., Porsani, J. L., \& Bortolozo, C. A. (2015). Preliminary Analysis of the Induced Magnetic Field in the TDEM Method: Applications in Fractured Aquifers. In 14th International Congress of the Brazilian Geophysical Society \& EXPOGEF (pp. 179-183). Rio de Janeiro: Brazilian Geophysical Society. https://doi.org/10.1190/sbgf2015-035

Danielsen, J. E., Auken, E., Jørgensen, F., Søndergaard, V., \& Sørensen, K. I. (2003). The Application of the Transient Electromagnetic Method in Hydrogeophysical Surveys. Journal of Applied Geophysics, 53, 181-198. https://doi.org/10.1016/j.jappgeo.2003.08.004

Drury, D. M. (1993). Hydrogeology of the Azraq Basin. Unpublished MSc Thesis, London: University College.

El-Kaysi, K., \& Talat, T. (1996). Geoelectrical Survey in the Azraq Mudflat Area. Report, Amman: Natural Resources Authority, Geophysics and Technical Service Department, Geophysics Division.

El-Waheidi, M. M., Merlanti, F., \& Pavan, M. (1992). Geoelectrical Resistivity Survey of the Central Part of Azraq Basin (Jordan) for Identifying Saltwater/Freshwater Interface. Journal of Applied Geophysics, 29, 125-133. https://doi.org/10.1016/0926-9851(92)90003-4

Fainberg, E. (1999). TEM-Fast 48 Manual. Amsterdam: Applied Electromagnetic Research.

Gonçalves, R., Farzamian, M., Monteiro Santos, F. A., Represas, P., Mota Gomes, A., Lobo de Pina, A. F., \& Almeida, E. P. (2017). Application of Time-Domain Electromagnetic Method in Investigating Saltwater Intrusion of Santiago Island (Cape Verde). Pure and Applied Geophysics, 174, 4171-4182.

https://doi.org/10.1007/s00024-017-1642-7

Google Earth (2019). http://earth.google.com/web

Henton, E., Ruben, I., Palmer, C., Martin, L., Garrard, A., Thirlwall, M., \& Jourdan, A. L. (2018). The Seasonal Mobility of Prehistoric Gazelle Herds in the Azraq Basin, Jordan: Modelling Alternative Strategies Using Stable Isotopes. Environmental Archaeology, 23, 187-199. https://doi.org/10.1080/14614103.2017.1316432

Ibrahim, K. M. (1996). The Regional Geology of Al Azraq Area (p. 67). Bulletin, Amman: Geological Mapping Division, Geological Directorate, Map Sheet No. 35531, Natural Resources Authority.

Interpex (1994). TEMIXGL User Manual, Transient Electromagnetic Data Interpretation Software.

Jørgensen, F., Lykke-Andersen, H., Sandersen, P. B., Auken, E., \& Nørmark, E. (2003). Geophysical Investigations of Buried Quaternary Valleys in Denmark: An Integrated Application of Transient Electromagnetic Soundings, Reflection Seismic Surveys and Exploratory Drillings. Journal of Applied Geophysics, 53, 215-228.

https://doi.org/10.1016/j.jappgeo.2003.08.017 
Kaufman, A. A., \& Keller, G. V. (1983). Frequency and Transient Soundings. Amsterdam: Elsevier.

Keller, G. V. (1988). Rock and Mineral Properties. Electromagnetic Methods in Applied Geophysics, 1, 13-51. https://doi.org/10.1190/1.9781560802631.ch2

Keller, G. V., \& Frischknecht, F. C. (1966). Electrical Methods in Geophysical Prospecting. Oxford: Pergamon Press Inc.

McNeill, J. D. (1994). Principles and Application of Time Domain Electromagnetic Techniques for Resistivity Sounding (Technical Note TN-27). Rapport Technique, Geonics Limited.

McNeill, J. D. (1990). Use of Electromagnetic Methods for Groundwater Studies. In S. H. Ward (Ed.), Geotechnical and Environmental Geophysics, Vol. 1, Review and Tutorial (pp. 107-112). Washington DC: Society of Exploration Geophysics Investigations No. 5. https://doi.org/10.1190/1.9781560802785.ch7

Nabighian, M. N., \& Macnae, J. C. (1991). Time Domain Electromagnetic Prospecting Methods. In Electromagnetic Methods in Applied Geophysics (Vol. 2 (Part A), pp. 427-509). Tulsa, OK: Society of Exploration Geophysics.

https://doi.org/10.1190/1.9781560802686.ch6

Naylor, D., Al-Rawi, M., Clayton, G., Fitzpatrick, M. J., \& Green, P. F. (2013). Hydrocarbon Potential in Jordan. Journal of Petroleum Geology, 36, 205-236.

https://doi.org/10.1111/jpg.12553

Palacky, G. J. (1988). Resistivity Characteristics of Geologic Targets. In Electromagnetic Methods in Applied Geophysics (Vol. 1, pp. 53-129). Tulsa, OK: Society of Exploration Geophysicists. https://doi.org/10.1190/1.9781560802631.ch3

Powell, J. H. (1989). Stratigraphy and Sedimentation of the Phanerozoic Rocks in Central and South Jordan. Part B: Kurnub, Ajlun and Belqa Groups (130 p.). Bulletin 11. Amman: Geological Mapping Division, Natural Resources Authority.

Sandersen, P. B., \& Jørgensen, F. (2003). Buried Quaternary Valleys in Western Denmark-Occurrence and Inferred Implications for Groundwater Resources and Vulnerability. Journal of Applied Geophysics, 53, 229-248.

https://doi.org/10.1016/j.jappgeo.2003.08.006

Shahbaz, M., \& Sunna, B. (2000). Integrated Studies of the Azraq Basin in Jordan. In P. F. Folliott et al. (Eds.), Land Stewardship in the 21st Century: The Contributions of Watershed Management (pp. 149-157). Fort Collins, CO: US Department of Agriculture, Forest Service, Rocky Mountain Research Station.

Sharma, S. P., \& Baranwal, V. C. (2005). Delineation of Groundwater-Bearing Fracture Zones in a Hard Rock Area Integrating Very Low Frequency Electromagnetic and Resistivity Data. Journal of Applied Geophysics, 57, 155-166.

https://doi.org/10.1016/j.jappgeo.2004.10.003

Wheater, H. S. (1996). Wadi Hydrology: Process Response and Management Implications. In Proceedings of the UNESCO/NWRC/ACSAD Workshops on "Wadi Hydrology" and "Groundwater Protection"(pp. 3-6). Cairo: UNESCO. 